\title{
COMPOSITION AND RELATIONSHIP OF THE TERRESTRIAL FAUNAS OF EASTER, JUAN FERNANDEZ, DESVENTURADAS, AND GALAPÁGOS ISLANDS *
}

\author{
Guillermo Kuschel \\ Centro de Investigaciones Zoologicas \\ Universidad de Chile \\ Santiago, Chile
}

South America has a great number of offshore islands, particularly in the fjord region of southern Chile, but there are also other truly oceanic islands lying far from the mainland and composed entirely of volcanic material. In this paper I shall attempt to present a general account of the composition of the terrestrial faunas of the oceanic islands, and to show their relationships with the faunas of other regions, before discussing the origin and possible antiquity of their older elements. Easter Island, Juan Fernández, Desventuradas, and the Galápagos will be considered here, but the isolated Sala y Gomez and the Cocos and Malpelo islands will not be dealt with because they are not sufficiently well known. In table 1 is shown the location of the islands to be considered, together with other basic data (see also fig. 1).

\section{EASTER ISLAND}

This remote island has a low and uniform topography relieved by a few craters which have no human record of volcanic activity. It is fairly arid, having no streams, lakes, or swampland, and showing surface water only in the depths of three of the craters. Its climate is warm-temperate, with its rainfall evenly distributed through the year ( $\mathrm{Cfa}$ in the Köppen-Geiger classification).

It is the only island of the four with a native human population. Man and his domestic animals, particularly sheep, have been largely responsible for the impoverishment of the flora and for this reason Easter Island has only 31 species of flowering plants. Skottsberg, in 1928, was therefore able to say

* Presented at the TENTH PACIFIC SCIENCE CONGRESS of the Pacific Science Association, held at the University of Hawaii, Honolulu, Hawaii, U.S. A., 21 August to 6 September 1961, and sponsored by the National ACADEMY of SCIENCES, Bernice PaUahi Bishop MuSEUM, and the University of Hawail. 


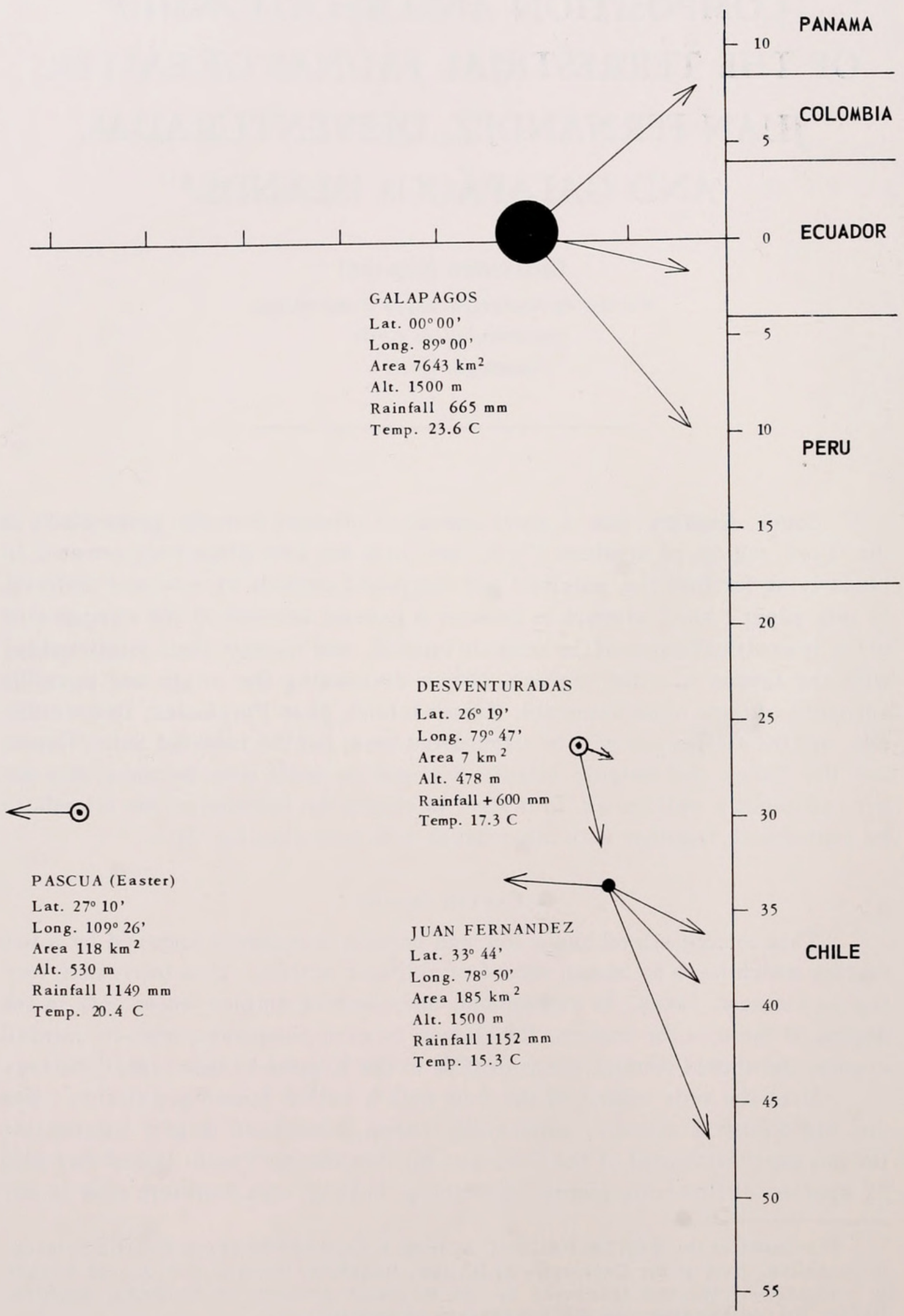


TABLE 1. Data on four island groups of the southeastern Pacific Ocean.

\begin{tabular}{l|c|c|c|c}
\hline & $\begin{array}{c}\text { PASCUA } \\
\text { (EasterIs.) }\end{array}$ & JUAN FERNANDEZ & DESVENTURADAS & GALÁPAGOS \\
\hline Latitude & $27^{\circ} 10^{\prime} \mathrm{S}$ & $33^{\circ} 37^{\prime} \mathrm{S}$ & $26^{\circ} 21^{\prime} \mathrm{S}$ & $00^{\circ} 00^{\circ}$ \\
Longitude & $109^{\circ} 26^{\prime} \mathrm{W}$ & $78^{\circ} 52^{\prime} \mathrm{W}$ & $79^{\circ} 7^{\circ} \mathrm{W}$ & $89^{\circ} 00^{\circ}$ \\
Area (km ${ }^{2}$ ) & 118 & 185 & 7 & 7643 \\
Max. altitude (m) & 530 & 1500 & 17.3 & 23.6 \\
Ann. Temp. C. & 20.4 & 15.3 & 600 & 665 \\
Rainfall (mm) & 1149.3 & 1152.2 & 859 & 950 \\
Distance from & & & & 1500 \\
\hline
\end{tabular}

in all fairness, "there does not exist another Island of the size of Easter and with such a fine climate where the native flora is so poor."

Although we would not expect a rich fauna on Easter Island it is quite clear that the fauna has become further impoverished and it is possible to point to certain features which, in this respect, distinguish Easter Island from others under consideration:

(1) The cosmopolitan or wide-spread element in its fauna is very high.

(2) The Indo-Malayan, or Pacific, element is also appreciable.

(3) Of the 79 terrestrial species of animal life only six are endemic and the position of even some of these is still debatable. These endemic species are:

a) Chrysopa skottsbergi Esben Petersen, 1924 (Neuroptera)

There is nothing published on its relationships with other species but it was most likely introduced from South America.

b) Lipsana insulae-paschalis Enderlein, 1940 (Diptera)

For this species Enderlein created a genus but gave no account at all of its relation to other genera. He also raised a new sub-family which he put in the Lonchaeidae.

c) Bidessus skottsbergi Zimmermann, 1924 (Coleoptera: Dytiscidae) This is said to be extremely close to two Australian species.

d) Pacindonus bryani (Swezey, 1921)

(Coleoptera: Curculionidae: Cossoninae)

The genus Pacindonus Kuschel is of Indo-Madagassian origin but is widely distributed through the Pacific. It has a dozen species or so, and is not represented in the Americas or in the cold-temperate regions.

Figure 1. Schematic position of the islands. Vertical line: South American continent, with the parallels. Horizontal line: the equator. Arrows: main relationships of the terrestrial fauna. 
TABLE 2. Climatological data for Easter Island.

\begin{tabular}{|c|c|c|c|c|c|}
\hline \multicolumn{2}{|c|}{ LATITUDE $27^{\circ} 10^{\circ} \mathrm{S}$} & \multicolumn{2}{|c|}{ LONGITUDE $109^{\circ} 26^{\prime} \mathrm{W}$} & \multicolumn{2}{|c|}{ ALTITUDE $41 \mathrm{~m}$} \\
\hline & $\begin{array}{c}\text { Mean max. } \\
\text { temp. C. }\end{array}$ & $\begin{array}{c}\text { Mean Temp. } \\
\text { C. }\end{array}$ & $\begin{array}{c}\text { Mean min. } \\
\text { temp. C. }\end{array}$ & $\begin{array}{l}\text { Relative } \\
\text { Humidity }\end{array}$ & $\begin{array}{c}\text { Rainfall } \\
\mathrm{mm} \text {. }\end{array}$ \\
\hline January & 27.0 & 23.1 & 19.1 & 78 & 104.9 \\
\hline February & 28.2 & 23.7 & 19.6 & 77 & 78.6 \\
\hline March & 27.4 & 23.1 & 19.3 & 77 & 100.9 \\
\hline April & 25.5 & 21.5 & 17.8 & 76 & 120.7 \\
\hline May & 23.4 & 19.9 & 16.9 & 80 & 114.7 \\
\hline June & 21.9 & 18.3 & 15.1 & 81 & 116.5 \\
\hline July & 21.4 & 17.8 & 14.6 & 83 & 88.6 \\
\hline August & 21.5 & 17.8 & 14.7 & 83 & 85.7 \\
\hline September & 22.1 & 18.1 & 14.5 & 82 & 75.7 \\
\hline October & 23.3 & 19.1 & 15.2 & 81 & 70.6 \\
\hline November & 24.2 & 20.2 & 16.3 & 83 & 90.5 \\
\hline December & 25.5 & 21.8 & 17.9 & 85 & 101.9 \\
\hline Annual & 24.3 & 20.4 & 16.8 & 81 & $1,149.3$ \\
\hline $\begin{array}{l}\text { Years of } \\
\text { observation }\end{array}$ & 34 & 34 & 34 & 28 & 47 \\
\hline
\end{tabular}

e) Tetragnatha paschae Berland, 1924 (Araneae)

The genus is of world-wide distribution and this species may possibly occur in other Pacific Islands.

f) Melampus pascus Odhner, 1922 (Mollusca)

This is of Oriental origin.

Of the six endemic species so far known, three are of Oriental origin, one of Australian origin, and the origin of two is as yet undetermined. So far, then, there is no proven South American element in the fauna, and Easter Island must be considered as one of the Pacific islands which have the IndoMalayan element as the strongest in their faunas.

\section{JUAN FERNANDEZ}

This is really a small archipelago comprising the islands of Masatierra, Santa Clara, and Masafuera, and Santa Clara may be counted a continuation of Masatierra, for it is separated from the western tip of the latter only by a narrow channel. Both Masatierra and Masafuera have a dense but varied cover of vegetation and this is particularly well developed around the higher hills of Masatierra. Only $170 \mathrm{~km}$. (92 miles) separate Masatierra and Masafuera, yet each has its own endemisms. Masafuera tops Masatierra by 600 metres, 
TABLE 3. Composition of the terrestrial fauna of Easter Island.

\begin{tabular}{|c|c|c|c|c|c|c|}
\hline & ENDEMICS & S. AMERICA & ORIENTAL & $\begin{array}{l}\text { AUSTR- } \\
\text { NEOZ. }\end{array}$ & $\begin{array}{c}\text { WIDE } \\
\text { SPREAD }\end{array}$ & UNDEFINED \\
\hline Oligochaeta & .. & .. & .. & .. & 1 & .. \\
\hline Isopoda & .. &.. & .. & . & ... & 2 \\
\hline Myriapoda & .. & .. & .. & .. & 2 & 1 \\
\hline Insecta & (4) & $(-)$ & (8) & (1) & $(42)$ & (2) \\
\hline Collembola & .. & .. &.$\cdot$ & .. & 1 & .. \\
\hline Odonata & .. & .. & .. & $\cdots$ & 1 & .. \\
\hline Blattariae & .. & .. & 3 & 1 & 1 & .. \\
\hline Orthoptera & .. & .. & 1 & .. & .. & .. \\
\hline Embioptera & .. & .. & 1 & .. &.. & .. \\
\hline Dermaptera & .. & .. & .. & .. & 1 & .. \\
\hline Thysanoptera & .. & .. & .. & .. & 1 & .. \\
\hline Psocoptera & .. & .. & .. & .. & .. & 1 \\
\hline Hemiptera & .. & .. & .. & .. & 9 & .. \\
\hline Neuroptera & 1 & .. & .. & .. & 1 & .. \\
\hline Lepidoptera & .. & .. & 2 & .. & 4 & .. \\
\hline Diptera & 1 & .. & .. & .. & 8 & .. \\
\hline Coleoptera & 2 & .. & 1 & .. & 8 & .. \\
\hline Hymenoptera & .. & .. & .. & .. & 7 & 1 \\
\hline Araneae & 1 & $\cdots$ & 2 & . & 4 & 2 \\
\hline Mollusca & 1 &. & 1 & 3 & $\cdots$ & 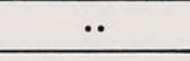 \\
\hline Vertebrata & $\cdots$ & $\cdots$ & 2 & $\cdots$ & .. & .. \\
\hline Total & 6 & .. & 13 & 4 & 52 & 7 \\
\hline
\end{tabular}

TABLE 4. Relationships of the fauna of Easter Island.

\begin{tabular}{l|c|c|c|c|c}
\hline & S. AMERICA & AUSTRALIA & $\begin{array}{c}\text { ORIENTAL- } \\
\text { POLYNESIAN }\end{array}$ & $\begin{array}{c}\text { WIDE } \\
\text { SPREAD }\end{array}$ & UNDEFINED \\
\hline Number of species & $\ldots$ & 2 & 16 & 52 & 9 \\
Percentage & $\ldots$ & 2.53 & 20.25 & 65.82 & 11.39 \\
\hline
\end{tabular}

its peaks are covered with snow in winter, and light falls of snow are common in summer. It is on these summits that the interesting Magellanic element of its flora is found.

Both islands have some permanent streams but they lack lakes and swampland. There are no volcanic craters asthough an eruption a century and a quarter ago (1835) took place off the extreme south-east of Cumberland Bay on Masatierra close to the coast.

Juan Fernandez has a warm temperate climate with rain throughout the year, but with considerably more precipitation in winter than summer $\left(\mathrm{Csb}_{2}\right.$ 
TABle 5. Climatological data of Juan Fernandez (Masatierra).

\begin{tabular}{|c|c|c|c|c|c|}
\hline \multicolumn{2}{|c|}{ LATITUDE $33^{\circ} 37^{\prime} \mathrm{S}$} & \multicolumn{2}{|c|}{ LONGITUDE $78^{\circ} 52^{\circ} W$} & \multicolumn{2}{|c|}{ ALTITUDE $6 \mathrm{~m}$. } \\
\hline & $\begin{array}{c}\text { Mean max. } \\
\text { temp. C. }\end{array}$ & $\begin{array}{c}\text { Mean te mp. } \\
\text { C. }\end{array}$ & $\begin{array}{c}\text { Mean min. } \\
\text { temp. C. }\end{array}$ & $\begin{array}{l}\text { Relative } \\
\text { Humidity }\end{array}$ & $\begin{array}{c}\text { Rainfall } \\
\mathrm{mm} . \\
\end{array}$ \\
\hline January & 21,7 & $18 \cdot 4$ & 15.2 & 74 & 24.9 \\
\hline February & 22.0 & 18.9 & 15.6 & 73 & 30.1 \\
\hline March & 21.0 & 18.3 & 15.1 & 74 & 39.8 \\
\hline April & 19.7 & 16.8 & 13.4 & 77 & 82.4 \\
\hline May & 17.8 & 15.2 & 12.0 & 79 & 149.0 \\
\hline June & 16.0 & 13.7 & 10.5 & 78 & 160.3 \\
\hline July & 15.1 & 12.9 & 9.8 & 80 & 142.0 \\
\hline August & $14 \cdot 7$ & 12.3 & 9.2 & 79 & 113.8 \\
\hline September & 15.2 & 12.4 & 9.4 & 77 & 76.8 \\
\hline October & 16.2 & $13 \cdot 3$ & 10.2 & 76 & 54.5 \\
\hline November & 18.0 & 15.0 & 11.7 & 74 & $34 \cdot 2$ \\
\hline December & 20.0 & 17.0 & 14.0 & 73 & 26.4 \\
\hline Annual & 17.9 & 15.3 & 12.2 & 76 & $1,152.2$ \\
\hline $\begin{array}{l}\text { Years of } \\
\text { observation }\end{array}$ & 35 & 35 & 35 & 35 & 48 \\
\hline
\end{tabular}

in the Köppen-Geiger classification). The lower-lying areas at some distance from the hills have a very dry summer and an arid soil that applies to the extreme west of Masatierra and to Santa Clara.

The flora includes 147 species of flowering plants. There are no native species of amphibians, reptiles, fresh-water fish, or mammals, but there are nine species of land-birds, all of which are related to the Chilean fauna.

According to Skottsberg (1956) there are 147 species of flowering plants on Juan Fernandez, and of these 101 are endemic. He divided the 147 species into 6 elements as below:

$\begin{array}{lrr}\text { Andine Chilean element } & 69 & 46.9 \% \\ \text { Subantartic Magellanian element } & 15 & 10.2 \% \\ \text { Neotropical element } & 19 & 12.9 \% \\ \text { Pacific element } & 26 & 17.7 \% \\ \text { Atlantic-S. African element } & 6 & 4.1 \% \\ \text { Eu-Fernandezian element } & 12 & 8.2 \%\end{array}$

It is most interesting to note here that the incidence of endemism, on a percentage basis, is very similar in the insects and flowering plants. It is not yet possible in the case of the insects to achieve the same precision of classification by origin which Skottsberg made for the plants, but the literature shows clearly enough that the southern Chilean element predominates strong- 
TABle 6. Composition of the terrestrial Arthropod fauna of Juan Fernandez.

\begin{tabular}{|c|c|c|c|c|c|}
\hline & $\begin{array}{l}\text { ENDEMIC } \\
\text { GENERA }\end{array}$ & $\begin{array}{r}\text { ENDEMIC } \\
\text { SPECIES }\end{array}$ & $\begin{array}{c}\text { NON-ENDEMIC } \\
\text { SPECIES }\end{array}$ & $\begin{array}{l}\text { UNDEFINED } \\
\text { SPECIES }\end{array}$ & $\begin{array}{c}\text { TOTAL NUMBER } \\
\text { OF SPECIES }\end{array}$ \\
\hline Isopoda & 1 & 8 & 3 &.. & 11 \\
\hline Myriapoda & .. & 3 & 6 & .. & 9 \\
\hline Insecta & $(54)$ & $(440)$ & $(170)$ & $(77)$ & $(687)$ \\
\hline Collembola & $\ldots$ & 3 & 5 & 4 & 12 \\
\hline Thys anura & .. & 2 & .. & .. & 2 \\
\hline Orthoptera & .. & 2 & 1 & 1 & 4 \\
\hline Dermaptera & .. & .. & 1 & . & 1 \\
\hline Isoptera & .. & 1 & .. & .. & 1 \\
\hline Psocoptera & .. & .. & .. & 4 & 4 \\
\hline Thysanoptera & .. & 2 & 2 & 2 & 6 \\
\hline Hemiptera & 8 & 32 & 7 & 9 & 48 \\
\hline Neuroptera & 1 & 4 & 1 & .. & 5 \\
\hline Trichoptera & .. & 2 & 1 & $\cdots$ & 3 \\
\hline Lepidoptera & 12 & 63 & 23 & 2 & 88 \\
\hline Diptera & 2 & 102 & 73 & 18 & 193 \\
\hline Coleoptera & 20 & 191 & 38 & 6 & 235 \\
\hline Hymenoptera & 11 & 38 & 15 & 31 & 84 \\
\hline Araneae & $\cdots$ & 13 & 6 & .. & 19 \\
\hline Pseudoscorpionida & 4 & 10 & $\cdots$ & 1 & 11 \\
\hline Acari & 1 & 26 & 2 & .. & 28 \\
\hline
\end{tabular}

1y. Second in importance, as in the case of the plants, comes the Pacific element, mainly Indo-Malayan.

\section{DESVENTURADAS}

These consist of the two tiny islands of San Felix and San Ambrosio and the islet called Gonzalez. This group lies $777 \mathrm{~km}$. (420 miles) to the north of Juan Fernandez and $859 \mathrm{~km}$. (464 miles) from the nearest point of the mainland.

San Ambrosio is larger, measuring roughly $4 \mathrm{~km}$. long by $1 \mathrm{~km}$. wide. Its coastline is very steeply countered and its upper parts constitute a plateau, lying between 300 and 478 metres above sea level, which is dissected by a few small and shallow ravines. Surface water and filtrations through the walls are totally absent except immediately after rain and for this reason the island is uninhabitable. There are no meteorological data for the Desventuradas but it is known that there is abundant rain in winter, while from October to March no rain falls and the summit is quite free from low clouds.

The prevailing wind is from the south-south-east. The vegetation is halophytic and though abundant on the plateau it is very scarce on the cliffs of the island. The island has only 19 native species of phanerogams and one moss, and there are no ferns at all. Terrestrial vertebrates are non-existent, 
TABle 7. Percentage of endemisms of Insecta and Phanerogamae.

\begin{tabular}{l|c|c|c|c}
\hline & ENDEMIC & NON-ENDEMIC & UNDEFINED & TOTAL NUMBER \\
\hline Insecta & 64.43 & 24.35 & 11.22 & 687 \\
Phanerogamae & 68.7 & 21.3 & $\ldots .$. & 147 \\
\hline
\end{tabular}

either native or introduced, but there are seven species of sea birds which nest on the island and there is one land-bird which is probably only the Juan Fernandez Sparrow Hawk (Falco sparverius fernandensis Chapman) which is most likely a recent immigrant.

San Ambrosio is one of the very few islands which has so far avoided invasion by any terrestrial vertebrates or by any weeds and has totally escaped the effects of fire.

San Felix Island is only a little. way to the west of San Ambrosio. It is smaller, lower $(170 \mathrm{~m}$. summit), and is less steeply sloped, it is much more arid and its vegetation is very sparse. It has some eight species of phanerogams, two of which are endemic.

Table 8. Composition of the terrestrial Arthropod fauna of San Ambrosio.

\begin{tabular}{|c|c|c|c|c|c|}
\hline & $\begin{array}{l}\text { ENDEMIC } \\
\text { GENERA }\end{array}$ & $\begin{array}{l}\text { ENDEMIC } \\
\text { SPECIES }\end{array}$ & $\begin{array}{c}\text { NON-ENDEMIC } \\
\text { SPECIES }\end{array}$ & $\begin{array}{l}\text { UNDEFINED } \\
\text { SPECIES }\end{array}$ & $\begin{array}{l}\text { TOTAL NUMBER } \\
\text { OF SPECIES }\end{array}$ \\
\hline Isopoda & .. & 2 & .. &.. & 2 \\
\hline Chilopoda &. & . & . & 2 & 2 \\
\hline Insecta & (4) & (16) & $(21)$ & $(37)$ & $(74)$ \\
\hline Collembola & .. & .. & .. & 1 & 1 \\
\hline Thysanura & .. & 1 & .. & 1 & 2 \\
\hline Orthoptera & .. & 1 & 1 & .. & 2 \\
\hline Psocoptera & .. & .. & .. & 3 & 3 \\
\hline Thysanoptera & .. & .. & .. & 1 & 1 \\
\hline Hemip tera & .. & 1 & 4 & 4 & 9 \\
\hline Lepidoptera & .. & .. & .. & 21 & 21 \\
\hline Diptera & 1 & 2 & 7 & 3 & 12 \\
\hline Coleoptera & 3 & 9 & 6 & 1 & 16 \\
\hline Hymenoptera & . & . & 3 & 4 & 7 \\
\hline Araneae & .. & .. & 5 & 2 & 7 \\
\hline Pseudoscorpionida & . & 2 &.. & .. & 2 \\
\hline Acari & .. & .. & . & $(20)$ & $(20)$ \\
\hline Gamasides & .. & .. & .. & 3 & 3 \\
\hline Uropodina & .. & .. & .. & 1 & 1 \\
\hline Trombidiformes & .. & .. & .. & 5 & 5 \\
\hline Acaridiae & .. & .. & .. & 1 & 1 \\
\hline Oribatei & .. & .. & .. & 10 & 10 \\
\hline
\end{tabular}


A point worth noting in table 8 is that the lepidopterous species outnumber both the Diptera and the Coleoptera.

As the first intensive collecting of the small animal life took place only at the end of 1960 , much of the material yet remains to be determined by specialists. Although the flora of the island only slightly resembles that of Juan Fernandez, the fauna is much more closely related. The percentage of endemism seems to be appreciably lower than on Juan Fernandez, but there are notable examples of endemism in both species and genera. Our knowledge to date enables us to distinguish four endemic genera in the Insecta, a genus of Calliphoridae related to Callyntropyga of Juan Fernandez, two genera of Curculionidae (Cossoninae) found only on Thamnoseris and related to the Juan Fernan$\operatorname{dez}$ fauna, and a carabid of problematical relationships, but certainly with no closely related genera in Juan Fernandez or on the Chilean mainland. A few other genera, formerly considered endemic in Juan Fernandez, are also represented on San Ambrosio, although not by the same species. It cannot be doubted that the terrestrial fauna of the Islas Desventuradas is closely related to that of Juan Fernandez unlike the flora which is only distantly related as a whole.

\section{GALÁPAGOS}

These islands form an archipelago situated on the Equator some $950 \mathrm{~km}$. (510) miles) from the nearest South American coast. They comprise 15 largish islands together with a host of smaller islands. Their total area is more than 40 times greater than Juan Fernandez and they offer a wider variety of environments, with arid and moist areas and with an altogether richer vegetation as they have nearly four times the number of plant species.

The terrestrial vertebrate fauna is comparably well known but the same cannot be said for the invertebrates. Information on the invertebrates is very widely scattered, so that it is extremely difficult to obtain a concise overall picture of the Galápagos fauna, but I have been able to collate all known papers on the Coleoptera and this is given in table 11 where it is compared with data for Juan Fernandez.

Wi thin any geographical zone there is a clear enough observable ratio of flowering plants to insects. The ratio varies with the incidence of endemism. On the basis of this ratio and the number of plants known to exist in the Galápagos Islands one would expect to find at least 550 to 800 species of Coleoptera, but up to now there are recorded only 190 species; that is to say, between a third and a quarter of the expected number. Moreover, the usual ratio of Carabidae to Curculionidae is roughly $1: 5$ and it is extremely strange that more Carabidae than Curculionidae are recorded for the Galápagos. From these facts we can only deduce that the Galápagos fauna has been selectively and incompletely collected. 
Table 9. Climatological data of San Cristóbal (Chatham I.), Galápagos.

\begin{tabular}{|c|c|c|c|c|c|}
\hline \multicolumn{2}{|c|}{ LATITUDE $00^{\circ} 54^{\circ} \mathrm{S}$} & \multicolumn{2}{|c|}{ LONGITUDE $08^{\circ} 37^{\circ} \mathrm{W}$} & \multicolumn{2}{|c|}{ ALTITUDE $2.7 \mathrm{~m}$. } \\
\hline & $\begin{array}{c}\text { Mean max. } \\
\text { temp. C. }\end{array}$ & $\begin{array}{c}\text { Mean temp. } \\
\text { C. }\end{array}$ & $\begin{array}{l}\text { Mean min. } \\
\text { temp. C. }\end{array}$ & $\begin{array}{l}\text { Relative } \\
\text { Humidity }\end{array}$ & $\begin{array}{l}\text { Rainfall } \\
\text { mm. }\end{array}$ \\
\hline January & 28.7 & 24.8 & 21.9 & 81 & 5.5 \\
\hline February & 29.8 & 25.8 & 22.9 & 82 & 190.1 \\
\hline March & 29.8 & 25.9 & 22.6 & 83 & 241.5 \\
\hline April & 30.0 & 25.9 & 22.8 & 84 & 141.8 \\
\hline May & 28.6 & 24.9 & 22.2 & 80 & 14.9 \\
\hline June & 27.8 & 23.8 & 21.4 & 77 & $5 \cdot 2$ \\
\hline July & 26.4 & 22.7 & 20.7 & 78 & 6.8 \\
\hline August & 25.6 & 21.7 & 19.6 & 79 & 8.4 \\
\hline September & 25.0 & 21.1 & 19.0 & 79 & 6.0 \\
\hline October & 25.5 & 21.7 & 19.2 & 76 & 6.8 \\
\hline November & 25.8 & 22.2 & 19.9 & 75 & 10.8 \\
\hline December & 27.1 & 23.2 & 20.9 & 77 & 26.6 \\
\hline Annual & 27.5 & 23.6 & 21.1 & 79 & 664.4 \\
\hline $\begin{array}{l}\text { Years of } \\
\text { observation }\end{array}$ & 3 & 7 & 3 & 5 & 3 \\
\hline
\end{tabular}

There is also a universally observed ratio between the endemism of phanagerogams and of the fauna, this being particularly true of the insects. From the table comparing the Coleoptera of the Galápagos and Juan Fernandez we can see that the incidence of endemism of Coleoptera species is about the same for both groups of islands, but for plants it is about 48 per cent for the Galápagos and is 68.7 per cent for Juan Fernandez; this seems to point to wrong interpretations in plant or Coleoptera studies somewhere, and the necessity for an intensive collection of invertebrates in the Galápagos is very apparent.

The Galápagos are further from the mainland than are the Desventuradas and Juan Fernandez and both flora and fauna are typically Neotropical, with few exceptions. A high percentage of the species of the Galápagos fauna has been found, by many authors, to be most closely related to the faunas of Central America, Mexico, and the Caribbean islands; but this is due more than anything to our ignorance of much of the fauna between Panama and northern Peru. Of the fauna I have personally been able to examine (Curculionidae), I am quite certain that the most closely related mainland species are those which live immediately opposite the Galápagos. There are some remarkable examples of Galápagos species being extremely closely related to species on Puna Island in the mouth of the Golfo de Guayaquil. 
TABLE 10. Climatological data of Seymour Island, Galápagos.

\begin{tabular}{l|c|c|c|c}
\hline & $\begin{array}{c}\text { Mean max. } \\
\text { temp. C. }\end{array}$ & $\begin{array}{c}\text { Mean temp. } \\
\text { C. }\end{array}$ & $\begin{array}{c}\text { Mean min. } \\
\text { temp. C. }\end{array}$ & $\begin{array}{c}\text { Rainfall } \\
\text { mm. }\end{array}$ \\
\hline January & 29.4 & 25.9 & 22.5 & 16.5 \\
February & 30.0 & 26.8 & 23.6 & 29.7 \\
March & 30.1 & 27.0 & 23.8 & 16.5 \\
April & 30.0 & 26.7 & 23.5 & 20.6 \\
May & 29.2 & 25.7 & 22.2 & 1.0 \\
June & 28.6 & 25.1 & 20.8 & 0.2 \\
July & 27.1 & 24.0 & 19.7 & 0.2 \\
August & 27.1 & 23.3 & 19.5 & 0.2 \\
September & 26.8 & 23.1 & 20.6 & 0.0 \\
October & 27.1 & 23.3 & 21.0 & 0.0 \\
November & 27.5 & 24.8 & 21.4 & 0.0 \\
December & 28.2 & 24.8 & & 85.6 \\
\hline Annual & 28.3 & 5 & 5 & 5 \\
\hline Years of & & 5 &
\end{tabular}

The occurrence of endemism in species and plants in the Galápagos is much lower than in Juan Fernandez.

\section{The Origin of the FaUnas of}

\section{Juan Fernandez, Desventuradas, and Galápagos}

As has been mentioned earlier, all these islands have today a purely volcanic bedrock and their degree of erosion has led geologists unanimously to believe that the islands cannot possibly be older than the Pliocene; that is to say, that they are not much more than ten million years old. We have to ask if this relatively short time, by geological standards, is sufficient to account for the clear difference observed between the faunas of the islands.

Geographically the Galápagos, Desventuradas, and Juan Fernandez are roughly the same distance from the South American coast and the line joining them is not far out of parallel with the line of the Andes. This makes one wonder if they might not have a common tectonic origin. It is also worthy of note that petrographic studies have shown very close similarity between the rocks of Masafuera and the Galápagos.

On the origin of life in these islands much has been written but the opinions expressed have differed greatly, expecially with regard to the Galápagos. There are those who passionately maintain that winds, sea currents, and birds 
are much more effective dispersal agents than is commonly conceded. That such agents do play a part in the repopulation of islands is not doubted, but as far as these particular islands are concerned it is easy enough to point to a series of components of the fauna which could not have been so transported, at least not across the natural barriers as they are today. I shall attempt to tackle this problem, beginning with Juan Fernandez and the Desventuradas.

Geological studies have shown that the Chilean coast south of Valparaiso had more or less the same coastline in the late Cretaceous as at the present. During the Eocene, however, we know that an important movement occurred between the 38th and 45th parallels, as this region completely lacks Eocene sedimentary rocks, and the next marine sediments to appear are of late Oligocene age, beginning with Navidad strata. This means that during the Eocene and most of the Oligocene there was formed a continuous ridge of land which cut off the present coast from the sea. This unstable mass was called "Land of Juan Fernandez" by Brüggen (1950) and this distinguished geologist presumed that this land extended obliquely northwards to Juan Fernandez, embracing the Desventuradas, for between these islands there is today a submarine chain nowhere deeper than $1.430 \mathrm{~m}$.

It is difficult to reconcile the proposed recent origin of the islands with our certain knowledge that Juan Fernandez and the Desventuradas contain an abundance of primitive elements in their flora and fauna and it is easier to accept Brüggen's hypothesis of the islands' origin. That is that, far from being of Pliocene or Pleistocene age, the islands are the relics of an older extensive land-mass which had direct connection with the continent or at least was very much closer to it than are the islands today, so permitting dispersal of the flora and fauna until the very late Tertiary when it is supposed a final subsidence isolated the present-day islands which are basically volcanic cones.

On the basis of Brüggen's hypothesis, which is founded on some geological facts, Skottsberg was able to understand and explain the Eocene flora of Juan Fernandez and also the high incidence of endemisms in genera and species. The occurrence of a subantarctic flora on the peaks of Masafuera, however, is still not satisfactorily explained for the ocean currents cannot be considered a likely means of transporting plants to island peaks, the presentday winds do not lie in the right direction, and we do not now observe bird migrations between southern Chile and Juan Fernandez. On the other hand, it is interesting to note that the subantarctic element in the flora is not paralleled in the fauna.

As far as the terrestrial fauna is concerned, with its remarkable degree of generic and specific endemism and its high percentage of species related to those in southern Chile, the hypothetical "Land of Juan Fernandez" accounts completely for its presence in the islands. Nevertheless, I would like to draw attention to two facts of importance: 
(1) The number of species of Coleoptera in the leaf litter is startlingly low despite the favorable conditions for development of such a faunal group. Most of the elements characteristic of southern Chile are missing, this being especially true of the Pselaphidae, Melandryidae, and Curculionidae (Cryptorhynchinae.)

(2) Among the flying insects, such as the Neuroptera and especially the Diptera, a large number of species are common to Juan Fernandez and southern Chile, or at least extremely closely interrelated, but many of these are found only in forests or their surrounds and not near the Chilean ports from which ships set sail for the islands. This makes it almost impossible for these species to have been transported to the islands by man's agency. While on the subject of flying insects, I might here interpolate some mention of certain birds which can scarcely have reached the islands under their own power in conditions as they are today; I have in mind such species as Spizitornis fernandezianus, Cinclodes oustaleti baeckstroemi, and Aphrastura masafuerae.

The first point, concerning the Coleoptera fauna of the leaf litter, seems to suggest that the Eocene fauna of the leaf litter lacked this element or, and perhaps more likely, that the "Land of Juan Fernandez" was not entirely continuous but interrupted here and there sufficiently to prevent the dispersal of those species belonging exclusively to the soil. We can hope to get nearer the truth of this matter once the hypogeous fauna has been carefully studied.

There is another geological fact worth mentioning here. Along the whole length of coast from the 5th parallel (Payta) in northern Peru to just beyond the 32 nd parallel (to the North of Valparaiso), there are found no marine sediments from the Eocene to the early Pliocene. This means that throughout this considerable period the coastline must have lain in what is now the Pacific Ocean, but we know nothing about this addition to the continental margin, which disappeared only in the late Pliocene. It is worth repeating here that the flora of San Felix and San Ambrosio is most closely related to that of Atacama, the mainland region immediately opposite the islands, and I might add that it is extremely difficult to account for this by means of the usual agents of dispersion, for neither atmospheric nor sea currents run in the required direction and birds do not now migrate from Atacama towards the islands.

On the origin of life on the Galápagos, if I may move on to this last group of islands, much has been written and one might almost say that the number of opinions equals the number of authors. If one compares its flora and fauna with that of Juan Fernandez, it is immediately apparent that its incidence of generic and specific endemisms is proportionally lower, and also, that its species do not display, as a whole, so many primitive features. On these grounds we do not expect such an early origin of life in the Galápagos as in Juan Fernandez and the Desventuradas. As there is an ample evidence of important geological changes throughout the whole of the Tertiary along 
TABLE 11. The Coleoptera of Galápagos and Juan Fernandez compared.

\begin{tabular}{|c|c|c|c|c|c|c|c|c|}
\hline & \multicolumn{4}{|c|}{ GALÁPAGOS } & \multicolumn{4}{|c|}{ JUAN FERNANDEZ } \\
\hline$c$ & Genera & $\begin{array}{l}\text { Endemic } \\
\text { genera }\end{array}$ & Species & $\begin{array}{l}\text { Endemic } \\
\text { species }\end{array}$ & Genera & $\begin{array}{c}\text { Endemic } \\
\text { genera }\end{array}$ & Species & $\begin{array}{r}\text { Endemic } \\
\text { species }\end{array}$ \\
\hline Cicindelidae & 1 & $\cdot$. & 2 & 2 & .. & .. & .. & .. \\
\hline Carabidae & 8 & $\cdots$ & 23 & 23 & 7 & 1 & 22 & 18 \\
\hline Dytiscidae & 4 & .. & 4 & 1 & 3 & 1 & 3 & 2 \\
\hline Gyrinidae & 1 & .. & 1 & 1 &.$\cdot$ & .. & .. & .. \\
\hline Hydrophilidae & 3 & 1 & 4 & 2 & .. & .. & .. & .. \\
\hline Limnebiidae & 1 & .. & 1 & 1 &.. & .. & .. & .. \\
\hline Staphylinidae & 2 & .. & 2 & 1 & 16 & 7 & 20 & 16 \\
\hline Ptiliidae & $\therefore$ &.. & .. & .. & 3 & .. & 5 & .. \\
\hline Scaphidiidae &.. &.$\cdot$ & .. & .. & 1 & .. & 1 & .. \\
\hline Histeridae & 2 & .. & 4 & 2 & 1 & .. & 1 & .. \\
\hline Passalidae & 1 & .. & 1 & .. &.$\cdot$ & .. & 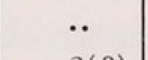 & .. \\
\hline Scarabaeidae & 3 & 1 & 5 & 4 & $1(?)$ &.. & $2(?)$ & . \\
\hline Trogidae & 1 & .. & 1 & .. & .. & .. &.. & .. \\
\hline Cantharidae & 1 & .. & 1 & $\cdot \cdot$ & $\cdot$. & .. & .. & .. \\
\hline Lycidae & 1 & .. & 1 & .. & .. & .. &.$\cdot$ &.$\cdot$ \\
\hline Meloidae & 1 & .. & 1 & $\ddot{n}$ & .. & .. & $\cdot$. & $\cdot \cdot$ \\
\hline Mordellidae & 1 & .. & 1 & 1 & $\cdot$. &.. & .. & $\ddot{*}$ \\
\hline Tenebrionidae & 9 & 2 & 40 & 37 & 3 & .. & 3 & 1 \\
\hline Alleculidae & 3 & .. & 4 & 3 &.$\cdot$ & .. &.$\cdot$ & .. \\
\hline Monotomidae & 1 & .. & 1 & 1 & .. & .. & .. & . \\
\hline Oedemeridae & 2 & .. & 5 & 4 &.. & .. & 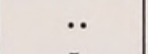 & .. \\
\hline Nitidulidae & 2 & .. & 2 & 1 & 1 &.. & 5 & 5 \\
\hline Cucujidae & 1 & .. & 1 & 1 &.$\cdot$ & .. & 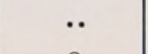 & 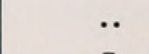 \\
\hline Cryptophagidae & 1 & .. & .. & .. & 4 & 2 & 8 & 7 \\
\hline Languriidae & 1 & $\cdot$. & 1 & .. & $\ddot{v}$ & .. & $\ddot{*}$ & $\ddot{r}$ \\
\hline Cisidae & .. & $\cdot \cdot$ & .. &.$\cdot$ & 1 &.$\cdot$ & 3 & 3 \\
\hline Lathridiidae & 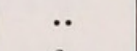 & .. &.$\cdot$ &.$\cdot$ & 4 & .. & 4 & 4 \\
\hline Colydiidae & 1 & .. & 1 & .. & 2 & .. & 4 & 4 \\
\hline Mycetophagidae & $\ddot{*}$ & .. & .. & .. & 1 & .. & 1 & * \\
\hline Elateridae & 7 & $\cdot \cdot$ & 14 & 12 & 1 & .. & 1 & .. \\
\hline Melasidae & .. & .. & .. & .. & 1 & .. & 1 & 1 \\
\hline Buprestidae & 2 &.$\cdot$ & 3 & 3 & 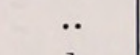 & .. & $\ddot{*}$ & .. \\
\hline Ostomidae & 2 &.$\cdot$ & 2 & 1 & 1 & 1 & 3 & 3 \\
\hline Cleridae & 2 & $\ddot{n}$ & 2 & 1 & 1 & 1 & .. & .. \\
\hline Dasytidae & 1 & 1 & 1 & 1 &.$\cdot$ & .. & .. & .. \\
\hline Dermestidae & 1 &.$\cdot$ & 2 & 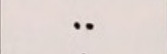 & 1 &.$\cdot$ & 1 & $\ddot{*}$ \\
\hline Anobiidae & 3 & .. & 4 & 4 & 5 & 1 & 8 & 2 \\
\hline Bostrichidae & & & & & & & & \\
\hline (+Lyctidae) & 3 & .. & $\begin{array}{l}3 \\
5\end{array}$ & $\ddot{3}$ & 2 & . & $\begin{array}{l}2 \\
3\end{array}$ & $\ddot{\vec{u}}$ \\
\hline Coccinellidae & 5 & .. & $\begin{array}{r}5 \\
18\end{array}$ & 3 & 2 & 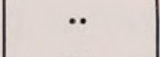 & 3 & 1 \\
\hline Cerambycidae & 12 & $\ddot{ }$ & 18 & $\begin{array}{r}14 \\
5\end{array}$ & $\ddot{1}$ & $\ddot{1}$ & $\ddot{3}$ & $\ddot{3}$ \\
\hline Chrysomelidae & 4 & 1 & 5 & 2 & .. & $\begin{array}{l}1 \\
. .\end{array}$ & .. & .. \\
\hline $\begin{array}{l}\text { Bruchidae } \\
\text { Anthribidae }\end{array}$ & 2 &.. & $\begin{array}{l}2 \\
1\end{array}$ & 1 & 1 & 1 & 1 & 1 \\
\hline $\begin{array}{l}\text { Anthribidae } \\
\text { Curculionidae }\end{array}$ & $\begin{array}{l}1 \\
9\end{array}$ & $\begin{array}{l}\ddot{*} \\
. \cdot\end{array}$ & 17 & 16 & 12 & 6 & 126 & 120 \\
\hline Scolytidae & 1 & .. & 1 & 1 & 2 & .. & 2 & .. \\
\hline Platypodidae & 1 & .. & 1 & 1 & $\cdot$. & $\cdot \cdot$ & .. & .. \\
\hline Total & 107 & 6 & 190 & 152 & 79 & 21 & 235 & 191 \\
\hline
\end{tabular}


TABLE 11. Continued

\begin{tabular}{|c|c|c|c|c|c|c|c|c|}
\hline & \multicolumn{4}{|c|}{ GALÁPAGOS } & \multicolumn{4}{|c|}{ JUAN FERNANDEZ } \\
\hline & Genera & $\begin{array}{c}\text { Endemic } \\
\text { genera }\end{array}$ & Species & $\begin{array}{l}\text { Endemic } \\
\text { species }\end{array}$ & Genera & $\begin{array}{l}\text { Endemic } \\
\text { genera }\end{array}$ & Species & $\begin{array}{r}\text { Endemic } \\
\text { species }\end{array}$ \\
\hline Families (total) & 39 & & & & 27 & & & \\
\hline $\begin{array}{l}\text { Families with } \\
\text { endemic subspeci }\end{array}$ & & & & 31 & & & & 16 \\
\hline $\begin{array}{l}\text { Percentage of } \\
\text { genera }\end{array}$ & 94.4 & 5.6 & & & 73.5 & 26.5 & & \\
\hline $\begin{array}{l}\text { Percentage of } \\
\text { species }\end{array}$ & & & 20 & 80 & & & 18.74 & 81.26 \\
\hline
\end{tabular}

the rest of the South American coast, we might expect there to have been similar disturbances along the coast of Ecuador and Colombia and, in fact, there is evidence of changes in short level in some fossiliferous raised beaches of late Tertiary age. The two submarine ridges, the Cocos Ridge which runs from Costa Rica to the north of the Galápagos, and the Carnegie Ridge which runs from Ecuador to the same islands, suggest a possible former union or closer proximity of islands and mainland. Shumway, however, discounts the former ridge by saying "the apparent absence of truncated seamounts on Cocos Ridge is evidence against a former emergence." Of the other submarine feature he says "on the basis of the bathymetry of Carnegie Ridge and the geological history of Colombia and Ecuador, it is speculated that the easternmost portion of Carnegie Ridge may once have been part of the western borderland for the early Tertiary geosyncline which existed along the present coastal lowland of western Ecuador. This would have shortened the sea route to the Galápagos Islands and possibly facilitated the rafting of plants and animals to the Islands."

The foregoing shows that there is yet no geological evidence of a land connection between the Galápagos and the continent in recent times and, in fact, dates any such connection as early Tertiary at the latest. This, however, hardly does more than deepen the mystery as the very close relationships between animal and plant species on the Galápagos and the continent are most striking and unquestionable, while other species on both mainland and islands are identical. If the origin of life in the Galápagos is placed as far back as the early Tertiary, then it seems impossible to understand the much lower degree of speciation and specialization of the terrestrial organisms on the Galápagos in comparison with those on Juan Fernandez, especially as the more favorable climate produces a higher turnover of genetic material. One would therefore expect to find an even greater difference in species between the Galápagos and the mainland than between Juan Fernandez and the continent. If 
I might be permitted to express a personal view, I would say without much hesitation after having studied my own group of the fauna of all the islands, and making the considerable assumption that one can extrapolate from this group, that the Galápagos' fauna is considerably younger than that of Juan Fernandez and the Desventuradas. I would also say that the fauna of these last two remote groups of islands mostly dates back to the Eocene and part of of the Oligocene, while the Galápagos fauna, including the terrestrial vertebrates, might go back only to the Pliocene or, even, to the end of the Pliocene and to the Pleistocene.

\section{SUMMARY}

After a brief description of Easter Island, Juan Fernandez, the Desventuradas, and the Galápagos, there follows a general account of the terrestrial faunas and their relationships with other biogeographic regions. All the basement rock now visible on the islands is volcanic and young in geological time, probably of the late Pliocene.

The incidence of endemisms in species, genera, and even higher systematic categories is considerably more in Juan Fernandez and the Desventuradas than in the Galápagos and it is concluded that most of the life on these former groups is of more ancient origin than in the Galápagos. Geological evidence suggests that during the Eocene there existed between parallels 38 and 45 along what is now the coast of Chile, an extension of the land surface which probably embraced Juan Fernandez and the Desventuradas. The structure of the basement rocks of these islands consisting of basalts and tuffs, also the small degree of erosion and denudation of the islands, do not indicate an age earlier than Pliocene for these two groups of islands. It is concluded that the last remnants of Brüggen's "Land of Juan Fernandez"' can only have disappeared finally beneath the sea in very recent times and this supposition is sufficient to explain the presence of the younger elements of the flora and fauna on these islands.

The date of the origin of life on the Galápagos is still an open field for speculation for, while sea bottom soundings have provided no evidence for the presence of emerged land of any sort between the continent and islands during the late Tertiary, the greater part of the Galápagos fauna, if not all of it, is relatively young. 


\section{LITERATURE CITED}

BRÜGGEN, J.

1950. Fundamentos de la Geología de Chile. Santiago, ed. 2, pp. 1-510, illustr. and maps.

SHUMWay, G.

1954. Carnegie Ridge and Cocos Ridge in the east equatorial Pacific. Journal of Geology, vol. 62, pp. 573-586.

SKOTTSBERG, C. ED.

1920-1956. History of Juan Fernandez and Easter Island, 3 vols., 688 pp. Uppsala, Almquist \& Wiksells Boktryckeri-A.-B.

SKotTSBerg, C.

1949. Die Flora der Desventuradas Inseln (San Felix und San Ambrosio), Goeteborgs Kungl. Vetensk apoch Vitterheis-Samhaelles $\mathrm{H}$ andlingar- Femte Foeljden, Ser. B, vol. 6, p. 3-88, 1937. (Spanish edition in Boletin Museo Nacional de Historia Natural, Santiago, vol. 24, pp. 1-64.

1945. The Juan Fernandez and Desventuradas islands, in Plants and Plant Science in Latin America, Waltham, Massachusetts, p. 150-153.

1951. Weitere Beitraege zur Flora der Insel San Ambrosio (Islas Desventuradas, Chile), Arkiv för Botanik, ser. 2, vol. 1, no. 12, pp. 453-459.

1957. The vegetation of the Juan Fernandez and Desventuradas Islands. Proceedings of the 8th Pacific Science Congress, vol.4, pp.181-185. 


\section{$2 \mathrm{BHL}$ Biodiversity Heritage Library}

Kuschel, Guillermo. 1963. "Composition and relationship of the terrestrial faunas of Easter, Juan Fernandez, Desventuradas, and Galápagos islands." Occasional papers of the California Academy of Sciences 44, 79-95. https://doi.org/10.5962/bhl.part.2341.

View This Item Online: https://www.biodiversitylibrary.org/item/22418

DOI: https://doi.org/10.5962/bhl.part.2341

Permalink: https://www.biodiversitylibrary.org/partpdf/2341

\section{Holding Institution}

MBLWHOI Library

\section{Sponsored by}

MBLWHOI Library

\section{Copyright \& Reuse}

Copyright Status: In copyright. Digitized with the permission of the rights holder.

License: http://creativecommons.org/licenses/by-nc-sa/3.0/

Rights: https://biodiversitylibrary.org/permissions

This document was created from content at the Biodiversity Heritage Library, the world's largest open access digital library for biodiversity literature and archives. Visit BHL at https://www.biodiversitylibrary.org. 